\title{
TGF- $\beta 1$ modulates the homeostasis between MMPs and MMP inhibitors through p38 MAPK and ERK1/2 in highly invasive breast cancer cells
}

\author{
Luciana R Gomes, Letícia F Terra, Rosângela AM Wailemann, Leticia Labriola and Mari C Sogayar*
}

\begin{abstract}
Background: Metastasis is the main factor responsible for death in breast cancer patients. Matrix metalloproteinases (MMPs) and their inhibitors, known as tissue inhibitors of MMPs (TIMPs), and the membraneassociated MMP inhibitor (RECK), are essential for the metastatic process. We have previously shown a positive correlation between MMPs and their inhibitors expression during breast cancer progression; however, the molecular mechanisms underlying this coordinate regulation remain unknown. In this report, we investigated whether TGF- $\beta 1$ could be a common regulator for MMPs, TIMPs and RECK in human breast cancer cell models.

Methods: The mRNA expression levels of TGF- $\beta$ isoforms and their receptors were analyzed by qRT-PCR in a panel of five human breast cancer cell lines displaying different degrees of invasiveness and metastatic potential. The highly invasive MDA-MB-231 cell line was treated with different concentrations of recombinant TGF- $\beta 1$ and also with pharmacological inhibitors of P38 MAPK and ERK1/2. The migratory and invasive potential of these treated cells were examined in vitro by transwell assays.

Results: In general, TGF- $\beta 2, T \beta R I$ and T $\beta R \|$ are over-expressed in more aggressive cells, except for $T \beta R I$, which was also highly expressed in ZR-75-1 cells. In addition, TGF- $\beta$ 1-treated MDA-MB-231 cells presented significantly increased mRNA expression of MMP-2, MMP-9, MMP-14, TIMP-2 and RECK. TGF- $\beta 1$ also increased TIMP-2, MMP-2 and MMP-9 protein levels but downregulated RECK expression. Furthermore, we analyzed the involvement of p38 MAPK and ERK1/2, representing two well established Smad-independent pathways, in the proposed mechanism. Inhibition of p38MAPK blocked TGF- $\beta 1$-increased mRNA expression of all MMPs and MMP inhibitors analyzed, and prevented TGF- $\beta 1$ upregulation of TIMP-2 and MMP-2 proteins. Moreover, ERK1/2 inhibition increased RECK and prevented the TGF- $\beta 1$ induction of pro-MMP-9 and TIMP-2 proteins. TGF- $\beta 1$-enhanced migration and invasion capacities were blocked by P38MAPK, ERK1/2 and MMP inhibitors.

Conclusion: Altogether, our results support that TGF- $\beta 1$ modulates the mRNA and protein levels of MMPs (MMP-2 and MMP-9) as much as their inhibitors (TIMP-2 and RECK). Therefore, this cytokine plays a crucial role in breast cancer progression by modulating key elements of ECM homeostasis control. Thus, although the complexity of this signaling network, TGF- $\beta 1$ still remains a promising target for breast cancer treatment.
\end{abstract}

\section{Background}

Breast cancer is a worldwide health problem for women, since it is the first in incidence and the second in mortality among cancer types [1]. Similarly to the majority of solid tumors, the main death factor attributed to breast cancer is the process of cell spreading

\footnotetext{
* Correspondence: mcsoga@iq.usp.br

Instituto de Química, Departamento de Bioquímica, NUCEL (Núcleo de Terapia Celular e Molecular), Universidade de São Paulo, São Paulo 05508000, SP, Brazil
}

(ㄷ) 2011 Gomes et al; licensee BioMed Central Ltd licensee BioMed Central Ltd.2012. This is an Open Access article distributed under the terms of the Creative Commons Attribution License (http://creativecommons.org/licenses/by/2.0), which permits unrestricted use, distribution, and reproduction in any medium, provided the original work is properly cited. (metastasis) from primary tumor to secondary sites [2]. events, including the organized breakdown of the extracellular matrix (ECM) [3-5]. Matrix metalloproteinases (MMPs) and their specific inhibitors, known as tissue inhibitors of MMPs (TIMPs) and the membrane-associated MMP inhibitor (RECK), are essential regulators of ECM degradation [6-9].

The MMPs constitute a large family of endopeptidases, which are responsible for degrading almost all 
ECM components, with each ECM element being cleaved by a specific MMP or a set of MMPs [10]. Consistent with their role in tumor progression, high levels of several MMP family members have been shown to correlate with poor prognosis $[11,12]$. Among the several MMPs previously related to breast cancer progression, the gelatinases (MMP-2 and MMP-9) stand out for their collagen type IV specific degradation capacity, in view of the fact that it is an abundant ECM component $[13,14]$. In association with TIMP-2, MMP-14 is involved in MMP-2 activation, being also correlated with breast cancer progression [15]. Given that ECM proteolysis is related to important physiological and pathological processes, homeostasis of the ECM degradation is tightly controlled by the balance between MMPs and MMP inhibitors [6-9].

Together, the secreted tissue inhibitors of MMPs (TIMPs) are able to reversibly inhibit the activity of all MMPs family members. Although first described as anti-invasive molecules, high levels of TIMP-1, TIMP-2 and TIMP-4 $[12,16,17]$ have been associated to adverse prognostic and cellular aggressiveness in breast tumors. This apparently controversial expression profile of TIMPs could be the result of their recently described role as multifunctional molecules [8]. The membraneassociated MMP inhibitor, RECK (reversion-inducing cysteine-rich protein with Kazal motifs), is able to suppress tumor invasion and metastasis by negatively regulating MMP-2, MMP-9 and MMP-14 [9,18,19]. As reviewed by Noda and Takahashi [19], RECK is described as a good prognosis marker, and several prior reports have demonstrated that RECK expression is decreased during cancer progression $[9,19]$. However, its role in breast cancer remains unclear, since no functional analysis of the RECK gene is yet available for this model. Moreover, unlike other cancer types, previous results from our laboratory showed that RECK transcript levels are higher in highly invasive and metastatic cell lines compared to less aggressive breast cell lines [12].

We have previously shown a significantly positive correlation between the mRNA expression levels of MMPs, TIMPs and RECK, both in cell line models as well as in tumor tissue samples [12], suggesting that the expression of these molecules, at least at the transcriptional level, may be regulated by common factors and signaling pathways in breast cancer. Like that of MMPs and their inhibitors, a high expression of TGF- $\beta 1$ (Transforming growth factor- $\beta$ 1) has been positively correlated with metastasis and tumor aggressiveness in mammary models [11]. Because TGF- $\beta 1$ has been shown to be involved in mechanisms regulating the expression and activity of some MMPs and/or MMP inhibitors in different models, [20-28], this cytokine seemed to be an interesting candidate to be tested as a common modulator of both types of molecules.

TGF- $\beta$ is a multifunctional cytokine, which modulates a wide variety of biological processes, including cell growth, differentiation, apoptosis, immunity, extracellular matrix production, angiogenesis, migration and invasion $[29,30]$. However, TGF- $\beta$ may induce entirely different cellular responses, depending on the cell type and stimulation context, both under physiological and pathological conditions $[29,31]$. Similarly, the role of TGF- $\beta$ in cancer progression has been shown to be multifaceted, given that this cytokine acts as a potent growth inhibitor, as an inducer of EMT (epithelial-mesenchymal transition) as well as a metastasis inducer, depending on the tumor stage [32-34]. TGF- $\beta$ isoforms (TGF- $\beta 1$, TGF- $\beta 2$ and TGF- $\beta 3$ ) signal after binding to their transmembrane serine/threonine kinase receptor type II (T $\beta$ RII), followed by association and trans-phosphorylation of TGF- $\beta$ receptor type I (T $\beta R I)$. In addition to the classical TGF- $\beta$-induced signal transduction by Smads, it is well known that this cytokine also signals in a Smad-independent manner, by induction of other pathways, such as the extracellular signal-regulated kinase $1 / 2($ ERK1/2) and the p38 MAP kinase (p38 MAPK) [35]. Previous reports have shown the direct function of these MAPK pathways in signal transduction of TGF- $\beta$-modulated cellular migration and invasion $[21,35]$.

In the present study, we investigated the role of TGF$\beta 1$ as a common regulator for MMPs, TIMPs and RECK in highly invasive human breast cancer cells and the involvement of the ERK1/2 and p38 MAPK pathways in this mechanism.

\section{Methods}

\section{Reagents}

The recombinant TGF- $\beta 1$ and the neutralizing antibody anti-TGF- $\beta 1$ were from R\&D Systems (Minneapolis, MN, USA). Antibodies against MMP-14 (113-5B7), TIMP-1 (7-6 C), TIMP-2 (67-4H11) and T1MP-3 (13613H4) were purchased from Merck (Darmstadt, Germany). Antibodies against p-ERK1/2, GAPDH and $\beta$ Tubulin were obtained from Santa Cruz (Santa Cruz, CA, USA). The antibodies against p-p38 MAPK, total ERK1/2, total p38 MAPK and RECK were purchased from Cell Signaling (Beverly, MA, USA). The pharmacological inhibitors against p38 MAPK (SB203680) and ERK1/2 (PD98059) were obtained from Tocris Bioscience (Bristol, UK). The broad-spectrum MMP inhibitor (GM6001) was purchased from Millipore (Billerica, MA, USA).

\section{Cell lines and culture conditions}

Five human breast cancer cell lines displaying different degrees of invasiveness and metastatic potential were 
used in this study [12]. The MCF-7 and Hs578T cell lines were maintained in phenol red-free Dulbecco's Modified Eagle Medium (LGC Biotecnologia, Cotia, Brazil) supplemented with fetal bovine serum (Cultilab, Campinas, Brazil) to a final concentration of $10 \%$. The ZR-75-1, MDA-MB-231 and MDA-MB-435 were cultured in RPMI medium without phenol red (LGC Biotecnologia) supplemented with $10 \%$ fetal bovine serum. For MMPs and MMP inhibitors mRNA analysis by qRT-PCR, total RNA was extracted when these cells achieved $80-90 \%$ confluence. For TGF- $\beta 1$ treatment, the MDA-MB-231 cells were plated in serum-containing medium and then serum-starved in a final concentration of $0.1 \%$ overnight prior to treatment with TGF- $\beta 1$ (10 $\mathrm{ng} / \mathrm{mL}$ ). In the "loss of function" study these cells were treated with different concentration of anti-TGF- $\beta 1$ antibody, being that the range of tested concentrations $(1,10,25$ or $50 \mathrm{ng} / \mathrm{mL})$ include those recommended by the manufacturer. The ERK1/2 or p38 MAPKs inhibitors were added $1 \mathrm{~h}$ prior to TGF- $\beta 1$ treatment. The MDA-MB-231 cells were treated with TGF- $\beta 1$ for $20 \mathrm{~h}$.

\section{Quantitative RT-PCR studies}

Total RNA from cell lines cultured and treated as described above was extracted using the RNAspin Mini Kit (GE Healthcare, Waukesha, WI, USA). For cDNA synthesis, $1 \mu \mathrm{g}$ of total RNA was reverse-transcribed using oligo-dT primers and the Superscript Amplification System (Life Technologies, Carlsbad, CA, USA). Quantitative RT-PCR was carried out using SYBR Green PCR Master Mix (Life Technologies). Table 1 shows the primers used, with the optimal concentration (in the range of $100 \mathrm{nM}$ to $600 \mathrm{nM}$ ). The cycling conditions were $50^{\circ} \mathrm{C}$ for $2 \mathrm{~min}, 95^{\circ} \mathrm{C}$ for $10 \mathrm{~min}$, followed by 40 cycles of $95^{\circ} \mathrm{C}$ for $15 \mathrm{~s}$ and $60^{\circ} \mathrm{C}$ for $30 \mathrm{~s}$. The mRNA expression levels of GAPDH, HPRT and H-MBS genes were subjected to the GeNorm computational program analysis [36]. The HPRT and H-MBS transcriptional expression levels, classified as the two most stable genes according to GeNorm analysis, were used to calculate the GeNorm Normalization Factor used as the endogenous control for the qRT-PCR. The amplification efficiency analyzed was calculated for each gene from the given slope in a linear regression curve of $\mathrm{Ct}$ values versus log of cDNA concentration. The corresponding PCR efficiency $(E)$ of one cycle in the exponential phase was calculated according to the equation: $\mathrm{E}=10^{[-1 / \text { slope }]}$. Relative expression levels were calculated according to the Pfaffl model [37].

\section{Western blotting}

Cultures were washed with ice-cold PBS and then lysed with lysis buffer $(50 \mathrm{mM}$ Tris, $\mathrm{pH} 7.5 ; 300 \mathrm{mM} \mathrm{NaCl}$ and 5 mM EDTA, $\mathrm{pH}$ 8.0) supplemented with $1 \times$

\section{Table 1 Sequence of primers used}

\begin{tabular}{|c|c|}
\hline Gene & Oligonucleotide sequence $\left(5^{\prime}-3^{\prime}\right)$ \\
\hline \multirow[t]{2}{*}{ MMP-2 } & F: AGCTCCCGGAAAAGATTGATG \\
\hline & R: CAGGGTGCTGGCTGAGTAGAT \\
\hline \multirow[t]{2}{*}{ MMP-9 } & F: CACGCACGACGTCTTCCA \\
\hline & R: AAGCGGTCCTGGCAGAAAT \\
\hline \multirow[t]{2}{*}{ MMP-14 } & F: GCAGAAGTTTTACGGCTTGCA \\
\hline & R: TCGAACATTGGCCTTGATCTC \\
\hline \multirow[t]{2}{*}{ TIMP-1 } & F: CCGCAGCGAGGAGTTTCTC \\
\hline & R: GAGCTAAGCTCAGGCTGTTCCA \\
\hline \multirow[t]{2}{*}{ TIMP-2 } & F: CGACATTTATGGCAACCCTATCA \\
\hline & R: GGGCCGTGTAGATAAACTCTATATCC \\
\hline \multirow[t]{2}{*}{ TIMP-3 } & F: ATCACCTGGGTTGTAACTGCAA \\
\hline & R: CGCTCCAGAGACACTCGTTCTT \\
\hline \multirow[t]{2}{*}{ RECK } & F: TGCAAGCAGGCATCTTCAAA \\
\hline & R: ACCGAGCCCATTTCATTTCTG \\
\hline \multirow[t]{2}{*}{ TGF- $\beta 1$} & F: GGCCCTGCCCCTACATTT \\
\hline & R: CCGGGTTATGCTGGTTGTACA \\
\hline \multirow[t]{2}{*}{ TGF- $\beta 2$} & F: TCAAGAGGGATCTAGGGTGGAA \\
\hline & R: GGCARGCTCCAGCACAGAA \\
\hline \multirow[t]{2}{*}{ TGF- $\beta 3$} & F: CAGCTCTAAGCGGAATGAGCAG \\
\hline & R: TATAGCGCTGTTTGGCAATGTG \\
\hline \multirow[t]{2}{*}{$T \beta R I$} & F: AAGTCATCACCTGGCCTTGGT \\
\hline & R: TGCGGTTGTGGCAGATATAGAC \\
\hline \multirow[t]{2}{*}{$T \beta R \|$} & F: AATATCCTCTGAAGAACGACCTAA \\
\hline & R: TCCCACCTGCCCACTGTTA \\
\hline \multirow[t]{2}{*}{ PAl-1 } & F: GGCTGACTTCACGCGTCTITCAG \\
\hline & R: GTTCACCTCGATCTTCACTTTCTG \\
\hline \multirow[t]{2}{*}{ GAPDH } & F: ACCCACTCCTCCACCTTTGA \\
\hline & R: CTGTTGCTGTAGCCAAATTCGT \\
\hline \multirow[t]{2}{*}{ H-MBS } & F: TGGACCTGGTTGTTCACTCCTT \\
\hline & R: CAACAGCATCATGAGGGTTTC \\
\hline \multirow[t]{2}{*}{ HPRT } & F: TCATTATGCTGAGGATTTGGAAAG \\
\hline & R: GGCCTCCCATCTCCTTCATC \\
\hline
\end{tabular}

protease inhibitor mix (GE Healthcare). For protein phosphorylation analysis, a phosphatase inhibitor mix (GE Healthcare) was also added. The homogenate was centrifuged for $30 \mathrm{~min}$ at $12,000 \times \mathrm{g}$ and the supernatant fraction was then collected and stored at $-70^{\circ} \mathrm{C}$. Conditioned medium was concentrated using Centricon Centrifugal Filters (Millipore). The total protein content for each sample was quantified using a Bio-Rad kit (BioRad, Hercules, CA, USA). Equal amounts (50-100 $\mu \mathrm{g})$ of proteins from each extract were boiled in Laemmli's sample buffer containing $5 \% \beta$-mercaptoethanol for denaturation. The protein samples were fractionated by SDS-PAGE and then electro-transferred to nitrocellulose membranes, which were blocked and then incubated for $2 \mathrm{~h}$ at room temperature or overnight at $4^{\circ} \mathrm{C}$, depending on the antibody. Immunoreactive proteins were detected with an appropriate secondary horseradish peroxidasecoupled antibody (Vector, Burlingame, CA, USA) and 
visualized using ECL Western blot reagent (GE Healthcare). Quantitative densitometry of the electrophoretic bands images was carried out with the ImageQuant 5.2 software (GE Healthcare).

\section{Gelatin zymaography assays}

Gelatin zymography of conditioned medium was used to observe the levels of MMP-2 and MMP-9 produced by MDA-MB-231 cell lines treated with TGF- $\beta 1$ and/or MAPK inhibitors. These samples were separated in a $10 \%$ SDS-polyacrylamide gel electrophoresis co-polymerized with the enzyme substrate, $0.1 \%$ denatured type I collagen (gelatin type A, Sigma, St. Louis, MO, USA), [38]. After eletrophoresis, the gels were washed at room temperature with $2.5 \%$ Triton X-100 in water for $1 \mathrm{~h}$ under orbital shaking. The washed gels were incubated for $48 \mathrm{~h}$ at $37^{\circ} \mathrm{C}$ in substrate buffer containing $50 \mathrm{mM}$ Tris buffer ( $\mathrm{pH} \mathrm{8.5)}$ and $10 \mathrm{mM} \mathrm{CaCl}_{2}$ and then stained with Coomassie Blue R-250 (Sigma) and destained with 40\% Methanol (Merck), 10\% Acetic Acid (Merck) in water. Gelatinolytic activity was visualized as negative staining bands, the image was inverted and the intensity of each band was normalized to the number of cells. Each independent experiment was performed in duplicate.

\section{Migration and invasion assays}

$1 \times 10^{4}$ MDA-MB-231 cells were plated in the top chambers of $8 \mu \mathrm{m}$ pore transwells (BD, Franklin Lakes, NJ, USA) in a low serum medium and pre-treated for 1 h with PD98059, SB203680 or GM6001. After this period of pre-treatment the medium at the bottom chamber was supplemented with $10 \mathrm{ng} / \mathrm{mL}$ of TGF- $\beta 1$. These cells were allowed to migrate towards medium contained this cytokine over a period of $8 \mathrm{~h}$. To assess the invasive potential of this cell line, the same protocol as above described was used with matrigel-coated transwells (BD Biosciences). In the invasion assays the cells were allowed to invade for $24 \mathrm{~h}$. Upon this period of time, cells at the top chamber were removed and the cells at the bottom of the filter were stained and fixed with Coomassie Blue $0.125 \%$ in methanol: acetic acid: $\mathrm{H}_{2} \mathrm{O}(45: 10: 45, \mathrm{v} / \mathrm{v} / \mathrm{v})$ for $15 \mathrm{~min}$. The number of cells per filter was counted on images from Nikon microscope using $10 \times$ objective lens. Duplicate wells were used per condition in each independent experiment.

\section{Statistical analysis}

All statistical analyses were performed using the GraphPad Prism 5.0 program. Results are presented as mean \pm standard deviation. Statistical significance was determined using the nonparametric KrusKal-Wallis test and the Dunns post test. Statistically significant differences were considered when $p<0.05$. One way ANOVA variance analysis and Tukey-Kramer test were employed to calculate $p$-values in migration and invasion assays.

\section{Results \\ Aggressiveness of breast cancer cell lines correlates with the expression levels of the MMPs and their inhibitors and with the TGF- $\beta$ isoforms and receptors}

Previous results from our laboratory indicated a positive correlation between high mRNA expression levels of MMPs and their inhibitors with breast cancer progression, both in cellular models and in tumor tissue samples, with all five human breast cancer cell lines displaying different invasive and metastatic potential when maintained in culture for 3 or 5 days [12]. Since these cell lines display distinct growth rates upon the same time in culture, they end up achieving different confluence levels. Bachmeier and collaborators demonstrated that MMPs and MMP inhibitors are differentially expressed at distinct cellular densities [39]. This report showed that the mRNA expression levels of MMP-2, MMP-9, TIMP-1 and TIMP-2 are modulated by the percentage of cell confluence in the breast cancer cell lines, including MCF-7 and MDA-MB-231 [39]. For this reason, we first analyzed the mRNA expression levels of MMP-2, MMP-9, MMP-14, TIMP-1, TIMP-2, TIMP-3 and RECK, in the same panel of five human breast cancer cell lines, but now maintained in culture until achieving $80-90 \%$ confluence. The relative mRNA expression levels of MMP-2, MMP-14, TIMP-1, TIMP2 , TIMP-3 and RECK were, in general, higher in highly invasive and metastatic cell lines (MDA-MB-231, MDAMB-435 and Hs578T), when compared to less aggressive ones (MCF-7 and ZR-75-1) (Figure 1). The mRNA expression levels of MMP-2 were significantly elevated $(p<0.05)$ in the MDA-MB-435 and in the Hs578T $(p<$ $0.001)$ breast cancer cell lines relative to MCF-7 cells. Similarly, MMP-14 mRNA was significantly overexpressed in highly aggressive cells, such as MDA-MB-231 $(p<0.05)$ and Hs578T $(p<0.01)$ cells. The most invasive and metastatic cell line, Hs578T, displayed significantly higher mRNA expression levels of TIMP-1 $(p<$ $0.001)$ and TIMP-3 $(p<0.001)$ than the MCF-7 cell line. The expression of TIMP-2 was significantly higher $(p<0.01)$ in the most aggressive cell lines MDA-MB435 and Hs578T, when compared with the least invasive one (MCF-7). Unlike other MMPs and MMP inhibitors, the expression profile of MMP-9 presented an opposite pattern since its transcriptional levels were significantly lower $(p<0.05)$ in MDA-MB-435 cells as compared to MCF-7 (Figure 1).

In order to analyze whether TGF- $\beta$ could act as a common regulator of MMPs, TIMPs and RECK in human breast cancer cell models, we investigated whether these cellular models express key members of 


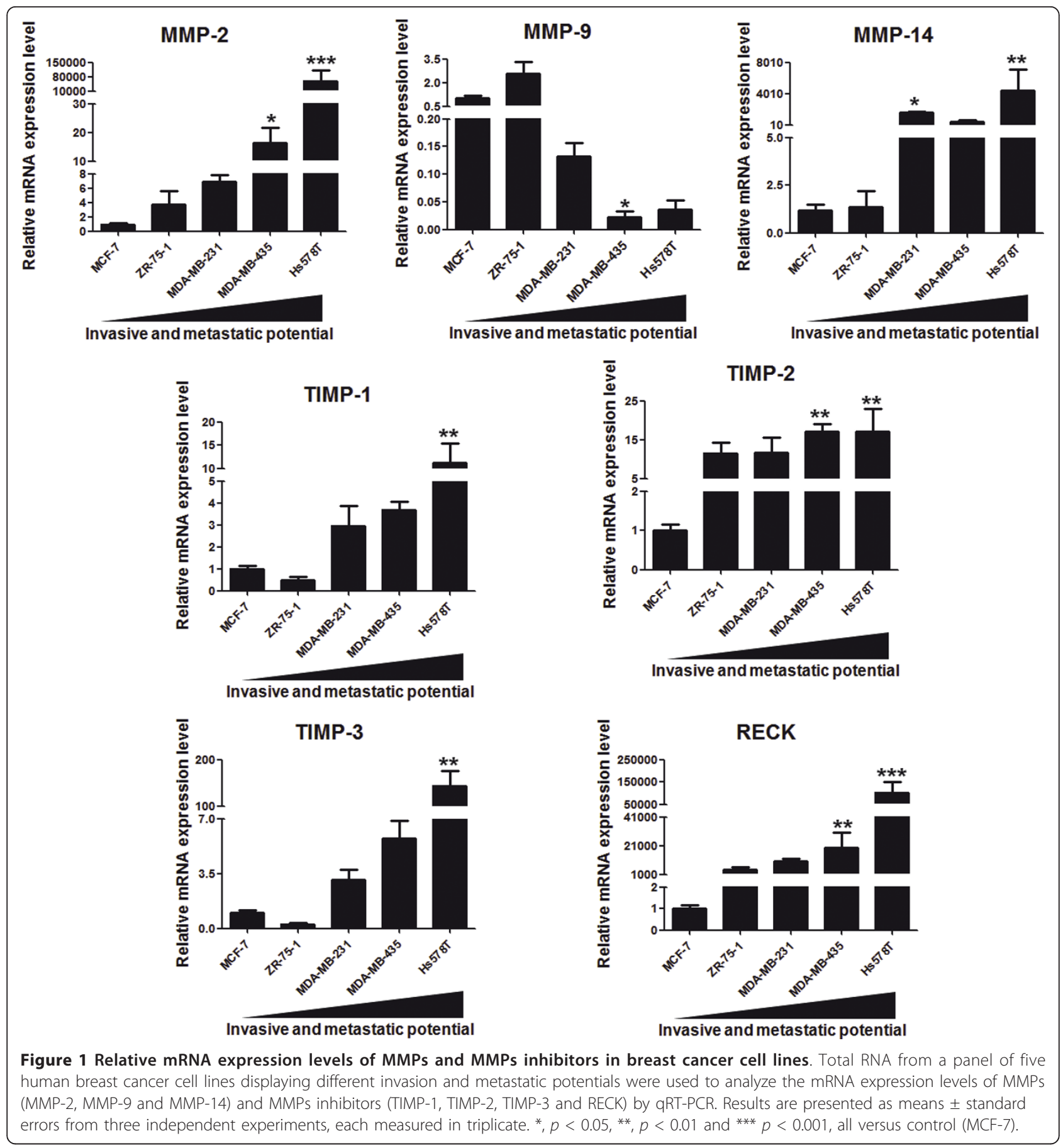

the TGF- $\beta$ network. Thus, we analyzed the mRNA expression levels of TGF- $\beta$ isoforms (TGF- $\beta 1$, TGF- $\beta 2$ and TGF- $\beta 3$ ) and their receptors (T $\beta$ RI and T $\beta$ RII) by qRT-PCR in this panel of five human breast cancer cell lines in cultures that had reached the same confluence level (Figure 2). Our results demonstrate that TGF- $\beta 2$ is significantly overexpressed in MDA-MB-231 $(p<0.01)$ and Hs579T $(p<0.001)$ cell lines relative to MCF-7.
Similarly, the TGF- $\beta$ receptors, T $\beta$ RI and T $\beta$ RII, were highly expressed in the most aggressive cell line Hs578T $(p<0.001$ and $p<0.05$, respectively). In contrast, the mRNA levels of TGF- $\beta 3$ were significantly lower $(p<$ 0.01 ) in the highly invasive MDA-MB-231 cell line relative to the least aggressive one (MCF-7). The TGF- $\beta 1$ transcriptional level was lower $(p<0.05)$ in ZR-75-1 cells than in MCF-7. Thus, these TGF- $\beta$ pathway 


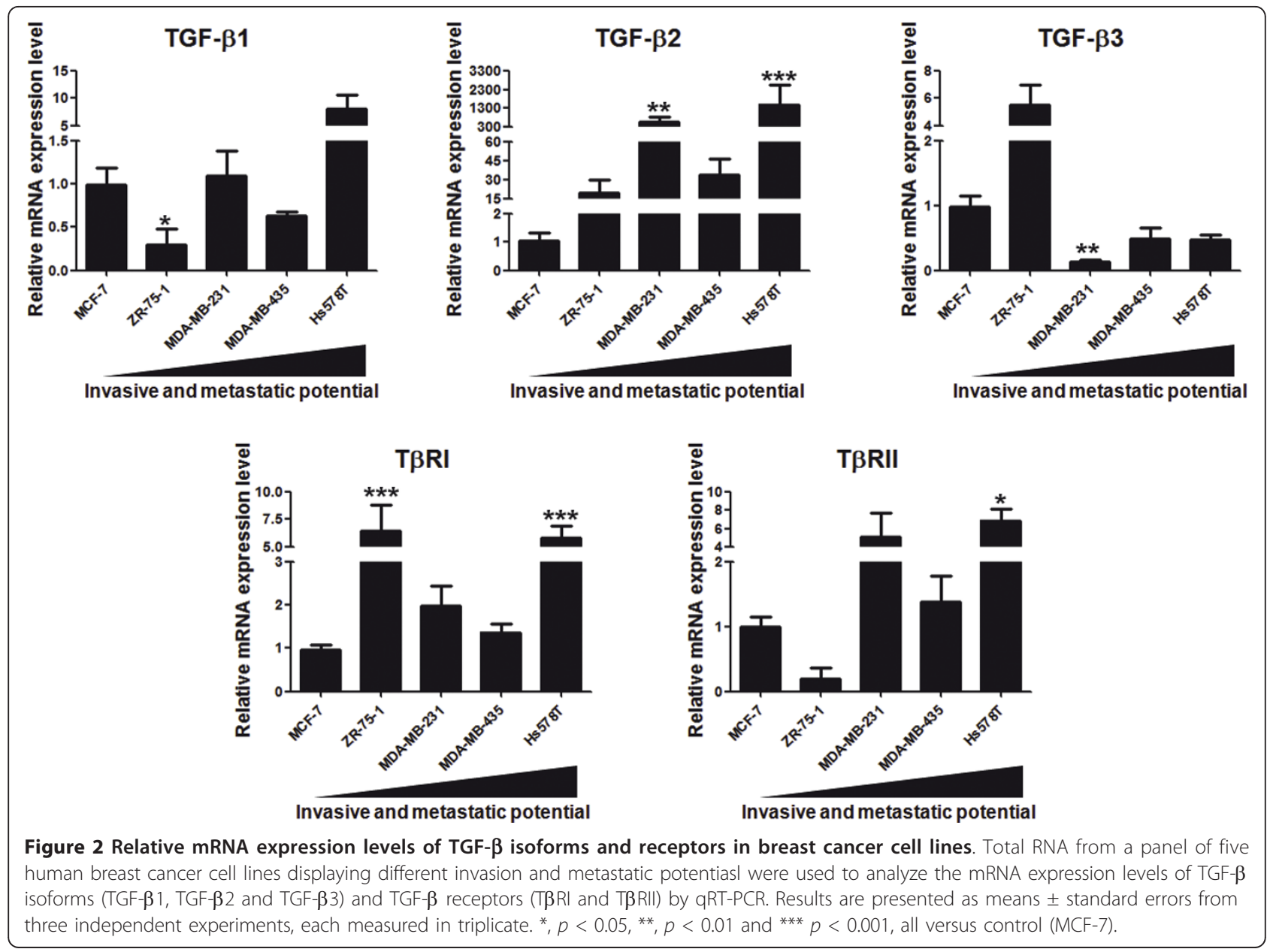

members are expressed by the cell lines included in this human breast cancer cell panel. These data also suggest that, following the same tendency as that of MMPs, TIMPs and RECK, the transcriptional levels of some TGF- $\beta$ isoforms and receptors are partially correlated with cellular aggressiveness.

\section{TGF- $\beta 1$ induces coordinate expression of MMP-2, MMP-9} and TIMP-2 in MDA-MB-231 breast cancer cells, but inhibits RECK protein expression levels

Cancer cells with different aggressiveness respond to TGF- $\beta 1$ treatment in distinct ways. In general, this cytokine plays a role as an invasion, EMT and metastasis inducer in advanced tumors [40,41]. Thus, in order to analyze the role of TGF- $\beta 1$ as a common regulator of the MMPs and their inhibitors in a breast cancer cell model, we treated the highly invasive MDA-MB-231 cell line with different concentrations $(0,1,5$ or $10 \mathrm{ng} / \mathrm{mL})$ of recombinant TGF- $\beta 1$ for $20 \mathrm{~h}$. The mRNA expression levels of PAI-I, a well-known TGF- $\beta 1$ transcriptional target, was used as a positive control for the MDA-MB231 treatment with this cytokine. As expected, we found a greater than 10 -fold increase in PAI-I expression in TGF- $\beta 1$-treated cells relative to untreated controls (Additional file 1 ) for all TGF- $\beta 1$ concentrations tested, confirming that this cell line was still responsive to TGF- $\beta 1$ treatment. Upon treatment with TGF- $\beta 1$, the MDA-MB-231 cell line showed significantly increased mRNA expression levels of MMPs (MMP-2, MMP-9 and MMP-14) and MMP inhibitors (TIMP-2 and RECK) (Figure 3). The mRNA expression of MMP-2 was significantly upregulated in MDA-MB-231 cells upon treatment with $1 \mathrm{ng} / \mathrm{mL}(p<0.05)$ and $10 \mathrm{ng} / \mathrm{mL}$ $(p<0.05)$ of TGF- $\beta 1$, relative to the untreated control cultures. Statistically significant increased transcriptional expression levels of MMP-9 were verified upon treatment of these cells with $1 \mathrm{ng} / \mathrm{mL}(p<0.05)$ and $5 \mathrm{ng} /$ $\mathrm{mL}(p<0.01)$ of recombinant TGF- $\beta 1$. The MMP-14 mRNA levels were also significantly increased in the MDA-MB-231 cells upon treatment with $1 \mathrm{ng} / \mathrm{mL}(p<$ $0.05)$ and $10 \mathrm{ng} / \mathrm{mL}(p<0.05)$ of TGF- $\beta 1$. The mRNA expression levels of the MMP inhibitors were also upregulated in TGF- $\beta 1$-treated MDA-MB-231 cells (Figure 3). TIMP-2 expression levels were higher in MDA-MB- 


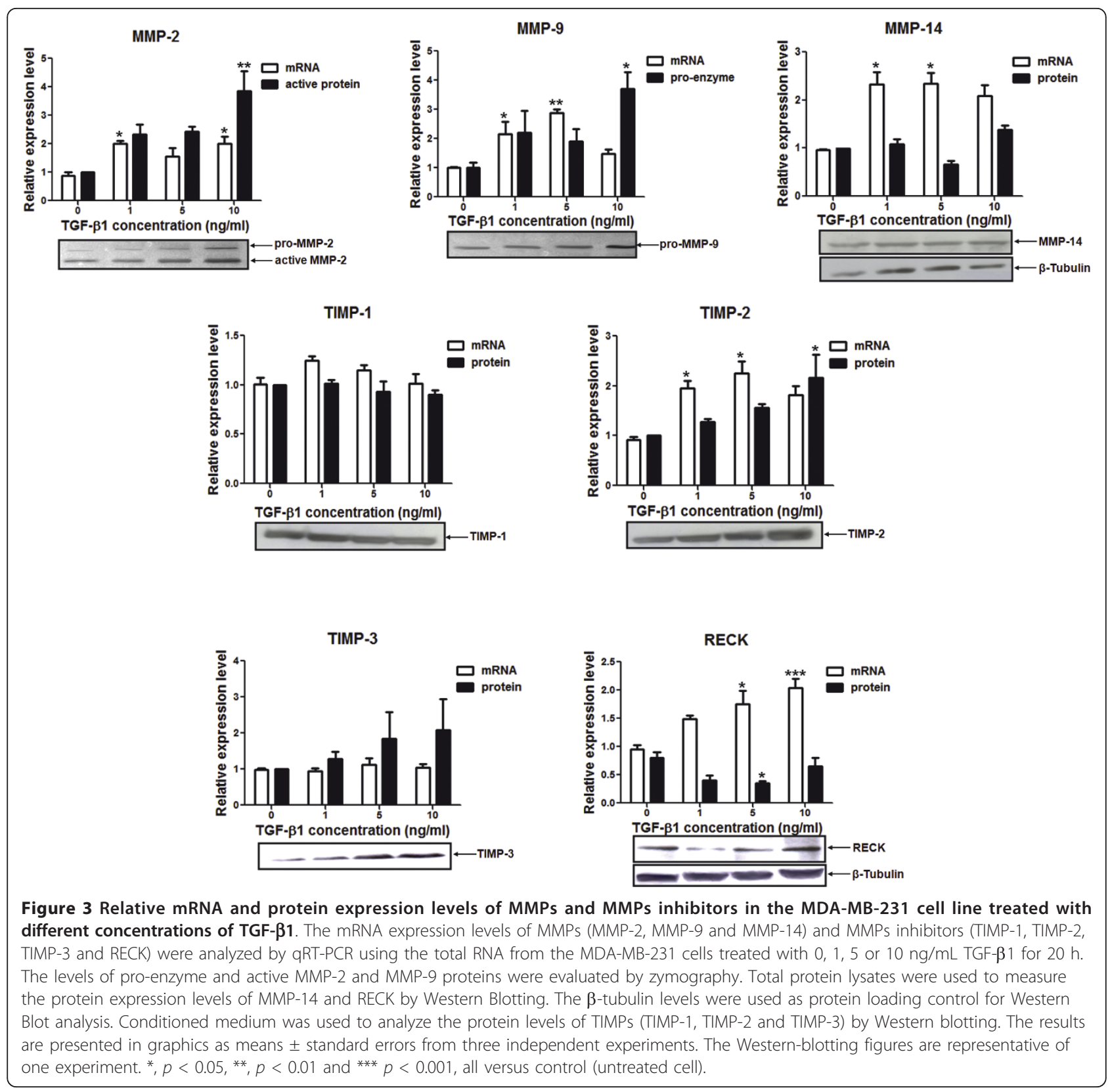

231 cells treated with $1 \mathrm{ng} / \mathrm{mL}(p<0.05)$ and $5 \mathrm{ng} / \mathrm{mL}$ $(p<0.05)$ of TGF- $\beta 1$ than in the untreated ones. Similarly, cells treated with $5 \mathrm{ng} / \mathrm{mL}(p<0.05)$ and $10 \mathrm{ng} /$ $\mathrm{mL}(p<0.001)$ of this cytokine displayed higher RECK mRNA levels than untreated cultures (Figure 3).

The treatment with recombinant TGF- $\beta 1$ was also able to increase the protein levels of MMP-2, MMP-9 and TIMP-2, but downregulated RECK protein levels (Figure 3). By Zymography assays, we verified that the active MMP-2 $(p<0.01)$ and the pro-enzyme MMP-9 $(p<0.05)$ levels were significantly increased in MDAMB-231 upon treatment with $10 \mathrm{ng} / \mathrm{mL}$ of TGF- $\beta 1$, relative to the untreated condition. Like MMPs, TIMP-2 protein levels were also significantly $(p<0.05)$ increased in MDA-MB-231 cells treated with the highest TGF- $\beta 1$ concentration tested. Conversely, RECK protein levels were decreased in TGF- $\beta 1$-treated MDA-MB-231 cells. This TGF- $\beta 1$-mediated downregulation of RECK protein levels was statistically significant at $5 \mathrm{ng} / \mathrm{mL}(p<0.05)$ treatment conditions (Figure 3). Altogether, these results support that TGF- $\beta 1$ modulates the mRNA and protein levels of MMPs (MMP-2 and MMP-9) as much as their inhibitors (TIMP-2 and RECK) in a dose-dependent manner. 
In order to obtain direct evidence of the role of TGF$\beta 1$ on modulation of the expression of MMPs and their inhibitors, a "loss of function" study was pursued. To this end, the endogenous TGF- $\beta 1$ activity of the MDAMB-231 cell line was inhibited by using a specific antibody for neutralization of this cytokine. The MDA-MB231 cells were treated with different concentrations $(0$, 1, 10, 25 or $50 \mathrm{ng} / \mathrm{mL}$ ) of anti-TGF- $\beta 1$ antibody for 24 h. As shown in the Additional File 1, the efficiency of TGF- $\beta 1$ activity blockage was confirmed, since the mRNA levels of PAI-I, a well known TGF- $\beta 1$ target, significantly decreased $(p<0.01)$ in cells subjected to higher antibody concentrations (25 and $50 \mathrm{ng} / \mathrm{mL}$ ). Subsequently, the effect of TGF- $\beta 1$ inhibition in the expression levels of MMPs and MMP inhibitors was assessed. The results, shown in Figure 4, demonstrated that treatment with the anti-TGF- $\beta 1$ antibody was able to significantly inhibit $(p<0.001)$ the mRNA expression levels of MMP-2, MMP-9, TIMP-2 and RECK in MDA-MB-231 cells.

\section{TGF- $\beta 1$ induces ERK1/2 and p38 MAPK phosphorylation} with distinct kinetics

To explore the role of ERK1/2 and p38 MAPK pathways in this proposed mechanism, we tested whether TGF- $\beta 1$ is able to induce phosphorylation of these signal

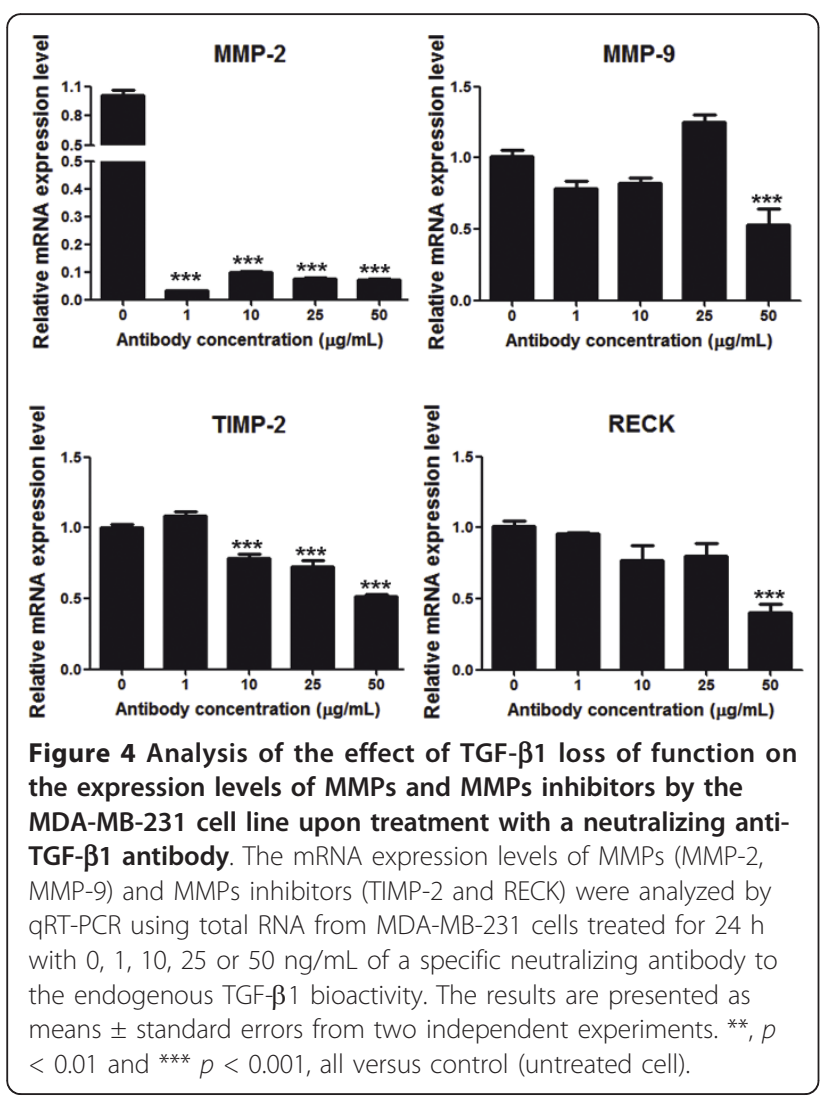

transduction proteins. Total protein extracts were obtained from MDA-MB-231 cells treated with $10 \mathrm{ng} /$ $\mathrm{mL}$ of TGF- $\beta 1$ for different periods of time $(0,5 \mathrm{~min}$, $10 \mathrm{~min}, 20 \mathrm{~min}, 30 \mathrm{~min}, 45 \mathrm{~min}, 1 \mathrm{~h}, 2 \mathrm{~h}$ and $3 \mathrm{~h}$ ) and the levels of ERK1/2 and p38 MAPK activation were analyzed by Western Blotting. As shown in Figure 5, TGF- $\beta 1$ treatment induced a significant phosphorylation $(p<0.05)$ of both ERK1/2 as well as p38 MAPK. We also observed that these MAPKs showed two activation peaks. The first one was reached shortly after TGF- $\beta 1$ addition (10 $\mathrm{min}$ and $30 \mathrm{~min}$ for $\mathrm{p}$-ERK1/2 and p-p38 MAPK, respectively) while the second one was achieved after longer periods of time of treatment with this cytokine (1 h for p-p38 MAPK).

Inhibition of ERK1/2 blocks TGF- $\beta 1$-mediated upregulation of MMP-9 and TIMP-2 and increases the level of RECK protein

The role of ERK1/2 pathway in TGF- $\beta 1$-mediated regulation of MMPs and MMP inhibitors was also evaluated. Different concentrations $(0,5,10$ or $20 \mu \mathrm{M})$ of an ERK1/ 2 pharmacological inhibitor (PD98059) were used to pretreat MDA-MB-231 cells for $1 \mathrm{~h}$. These cultures were further stimulated with $10 \mathrm{ng} / \mathrm{mL}$ of TGF- $\beta 1$ for $20 \mathrm{~h}$. By qRT-PCR, we found that the ERK1/2 inhibitor did not affect the TGF- $\beta 1$-mediated induction of MMP-2, MMP9, TIMP-2 and RECK mRNA expression mediated by TGF- $\beta 1$ treatment (Figure 6). However, the highest concentration of PD98059 significantly decreased $(p<0.001)$ the amount of MMP-9 and TIMP-2 protein levels following TGF- $\beta 1$ treatment. ERK1/2 inhibition not only blocked the TGF- $\beta 1$-mediated downregulation of RECK protein production, but also significantly increased RECK mRNA expression. Cells treated with $20 \mu \mathrm{M}$ of PD98059 and $10 \mathrm{ng} / \mathrm{mL}$ of TGF- $\beta 1$ presented significantly higher expression of RECK relative to cells treated with vehicle $(p<0.05)$ or with TGF- $\beta 1$ only $(p<0.001)$ (Figure 6$)$. These results suggest that the ERK1/2 activity is essential for the modulation of MMP-9, TIMP-2 and RECK expression by TGF- $\beta 1$.

\section{p38 MAPK inhibition blocked the TGF- $\beta 1$-mediated increase in MMP-2 and TIMP-2 protein levels}

The role of $\mathrm{p} 38$ MAPK in the proposed TGF- $\beta 1$-mediated mechanism was also investigated. MDA-MB-231 cells were pre-treated for $1 \mathrm{~h}$ with $0,5,10$ or $20 \mu \mathrm{M}$ of SB203680 (a p38 MAPK pharmacological inhibitor) followed by treatment with TGF- $\beta 1(10 \mathrm{ng} / \mathrm{mL})$. Inhibition of 338 MAPK pathway significantly blocked $(p<0.05)$ the TGF- $\beta 1$-induced upregulation of MMP-2, MMP-9, TIMP2 and RECK mRNA levels. Interestingly, lower concentrations of p38 MAPK inhibitor were required to abrogate the action of TGF- $\beta 1$ on mRNA levels of MMPs inhibitors (TIMP-2 and RECK) (Figure 7). 


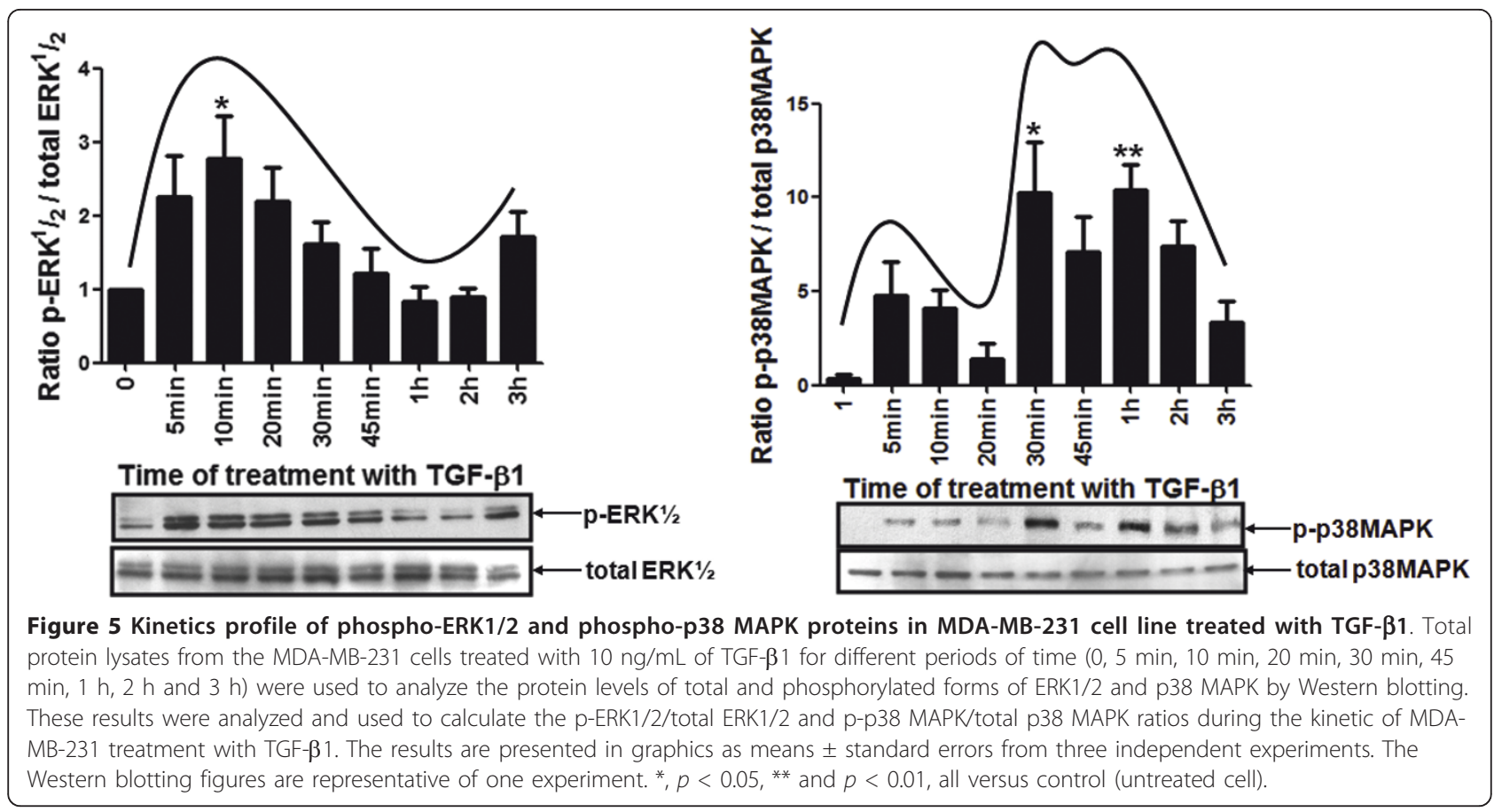

The highest SB203680 concentration tested was able to significantly $(p<0.05)$ inhibit the TGF- $\beta 1$-mediated induction of the active MMP-2 and TIMP-2 protein levels (Figure 7). On the other hand, inhibition of p38 MAPK did not have a significant effect on MMP-9 protein induction or RECK protein downregulation promoted by TGF- $\beta 1$ treatment. Together, these data led us to propose that $\mathrm{p} 38$ MAPK was responsible for the mediation of the TGF- $\beta 1$ effect on the MMP- 2 and TIMP-2 protein levels. It is important to note that unlike ERK1/2 pathway, p38 MAPK activity was not relevant for the TGF- $\beta 1$ modulation of MMP-9 and RECK expression.

\section{ERK1/2 and p38 MAPK pathways crosstalk in the MDA-} MB-231 cellular model

The above results indicated that ERK1/2 and p38 MAPK pathways were involved in the TGF- $\beta 1$-mediated regulation of MMPs and their inhibitors. Therefore, we investigated whether these signal transduction molecules could crosstalk in MDA-MB-231 cells upon activation by TGF- $\beta 1$. To this end, MDA-MB-231 cells were pretreated with $20 \mu \mathrm{M}$ of an ERK1/2 or p38 MAPK inhibitor (PD98059 and SB203680, respectively) for $1 \mathrm{~h}$ and then stimulated with $10 \mathrm{ng} / \mathrm{mL}$ of TGF- $\beta 1$. Since ERK1/ 2 and p38 MAPK displayed a different activation kinetics, upon the cellular pre-treatment with PD98059 or SB203680, we performed TGF- $\beta 1$ stimulation for periods of times corresponding to the maximal activation of each MAPK observed in the previous experiments
(Figure 5). Therefore, in addition to TGF- $\beta 1$, cells were treated with ERK1/2 inhibitor for $10 \mathrm{~min}$ and $3 \mathrm{~h}$ and with the SB203680 for $30 \mathrm{~min}$ and $1 \mathrm{~h}$.

TGF- $\beta 1$ stimulation of MDA-MB-231 cells for $3 \mathrm{~h}$ did not affect p38 MAPK activation (Figure 8A). However, the levels of p-p38 MAPK were significantly higher $(p<$ $0.05)$ in cells pre-treated with PD98059 relative to cells treated only with TGF- $\beta 1$ for the longest period of time. Addition of TGF- $\beta 1$ did not induce a significant change on p-p38MAPK accumulation in ERK $1 / 2$ inhibited cells (Figure 8A). However, treatment with SB203680 promoted a similar effect on p-ERK1/2 levels for $30 \mathrm{~min}$ of treatment (Figure 8B). TGF- $\beta 1$-treated cells had significantly lower $\mathrm{p}$-ERK $1 / 2$ protein $(p<0.001)$ when compared with MDA-MB-231 cells pre-treated with the p38 MAPK specific inhibitor (Figure $8 \mathrm{~B}$ ). These results suggest that the ERK1/2 and p38 MAPK pathways crosstalk in the MDA-MB-231 cell model. However, TGF- $\beta 1$ was apparently not involved in this signalling interaction.

\section{TGF- $\beta 1$-increased migration and invasion capacities of} MDA-MB-231 cells are dependent on ERK1/2, p38 MAPK and MMPs activities

Our results support the hypothesis that TGF- $\beta 1$ is a common regulator of molecules classically related to cell motility and invasive phenotype. Thus, we examined the effect of this cytokine on the migratory and invasive potential of MDA-MB-231 cells. TGF- $\beta 1$-treated MDA-MB-231 cells presented a significantly increased $(p<0.001)$ migration (Figure 9A) and invasion (Figure 9B) capacities, doubling 


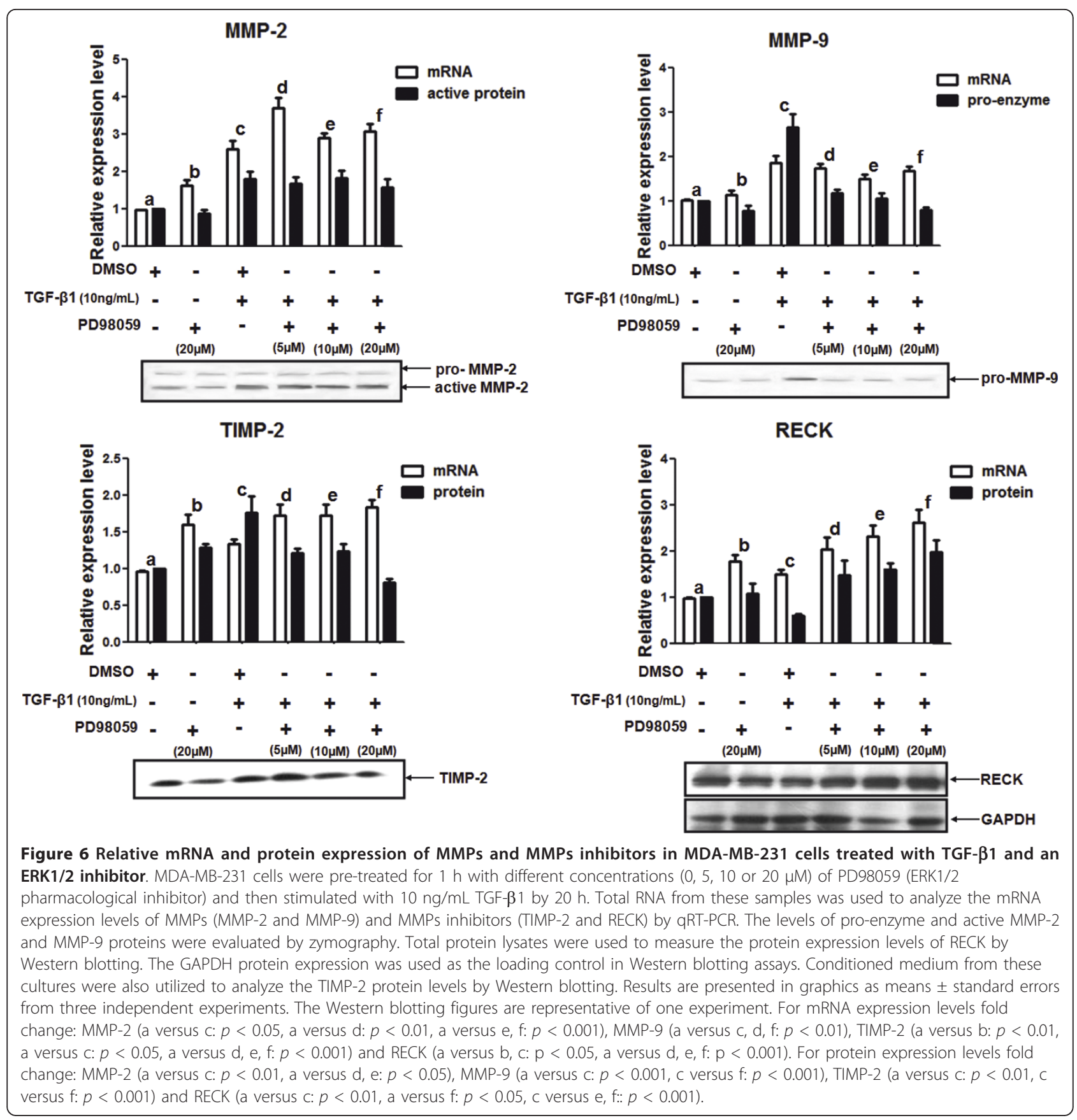

the number of cells present at the bottom of transwells. Moreover, we investigated whether ERK1/2, p38 MAPK and MMPs could act as mediators of this TGF- $\beta 1$ mediated effect in MDA-MB-231 motility. To this end, cells were pre-treated for $1 \mathrm{~h}$ with $20 \mu \mathrm{M}$ of either PD98059 or SB203680, or with $40 \mu \mathrm{M}$ of GM6001 (a broad-spectrum MMPs inhibitor), and then stimulated with $10 \mathrm{ng} / \mathrm{mL}$ TGF- $\beta 1$. Treatment of the MDA-MB-231 cell line only with ERK1/2, p38 MAPK or MMPs inhibitors did not have a significant effect in the migratory and invasive phenotype in relation to cells treated with vehicle (DMSO). However, all of these inhibitors were able to significantly block $(p<0.001)$ the TGF- $\beta 1$-induced migration and invasion potential of MDA-MB-231 cells, suggesting that TGF- $\beta 1$ indeed utilizes ERK1/2 and p38 MAPK to mediate the upregulation of MMPs.

\section{Discussion}

Metastasis is the final stage in tumor progression, being the main factor associated with cancer-promoted deaths 


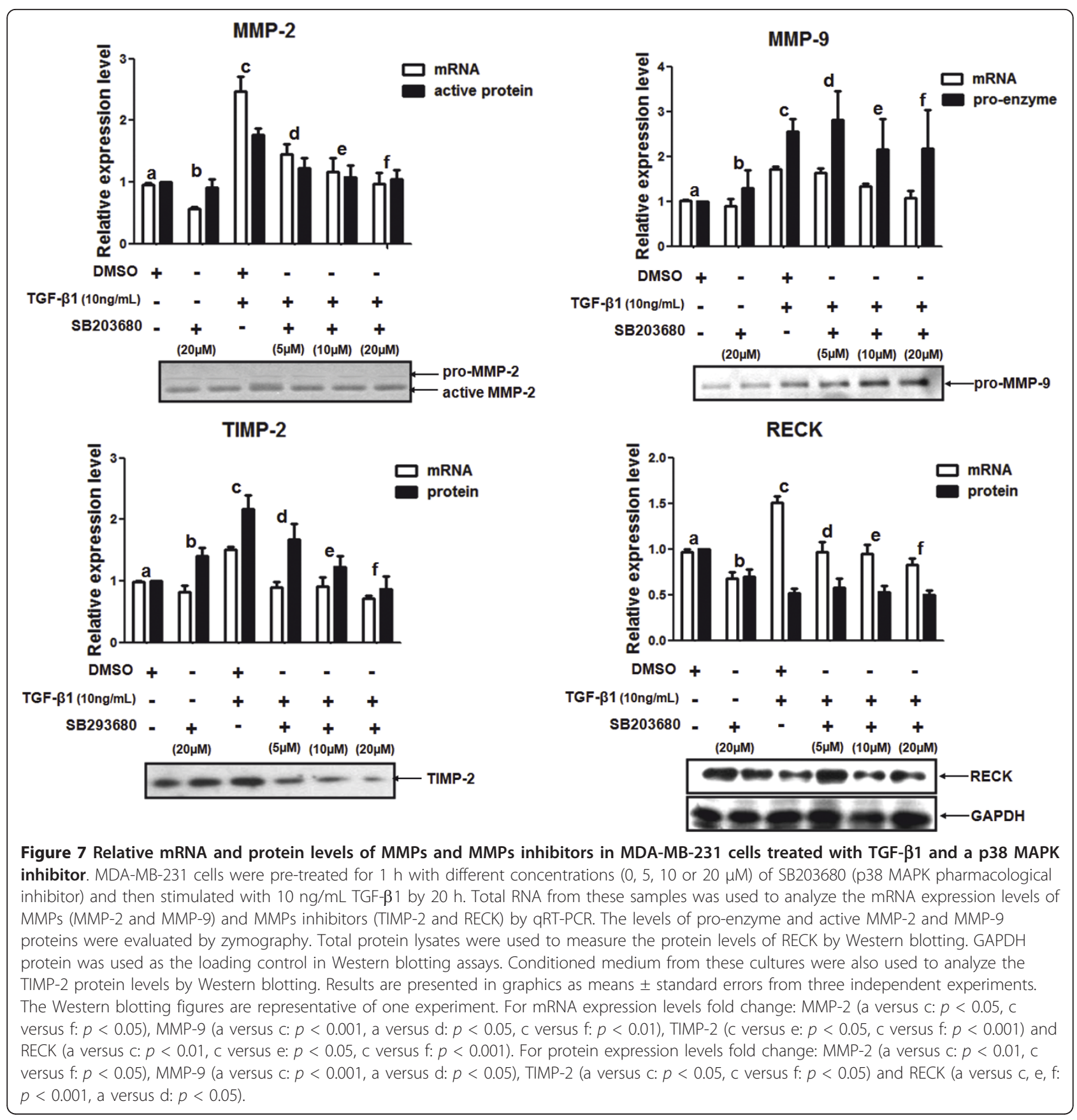

[42]. The balance between the activities of MMPs and MMP inhibitors is the essential regulator of ECM degradation and, consequently, of cellular phenotypes related to motile and invasive capacities. Similar to other cancer types, the breast cancer progression process is positively correlated with increased MMPs and MMP inhibitors expression and activity [12], suggesting a coordinate regulation mechanism. In this report, we demonstrated, for the first time, that TGF- $\beta 1$ is able to modulate MMP, TIMP and RECK expression in MDA-MB-231 human breast cancer cell line through ERK1/2 and p38MAPK. Both of these transducer pathways were essential to the TGF- $\beta 1$-enhanced migration and invasion phenotypes; however, each mediated the TGF- $\beta 1$ signal for MMPs and their inhibitors in a specific manner.

The important role of TGF- $\beta$ during multiple stages of cancer progression has been widely reported. However, the status of several members of this pathway in human cancers remains quite complex and unclear $[43,44]$. The TGF- $\beta$ receptors and their downstream transducers are 


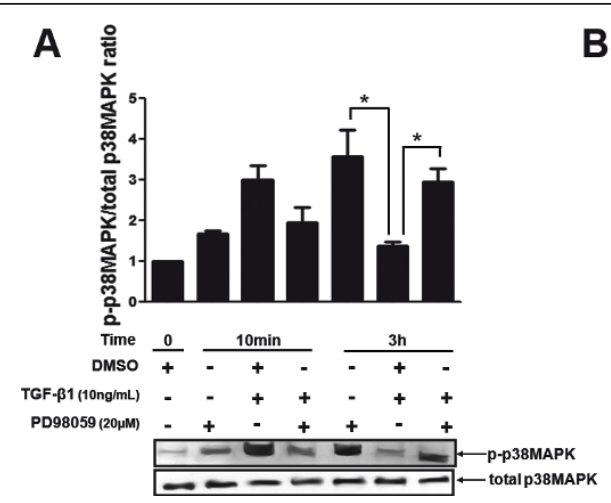

B

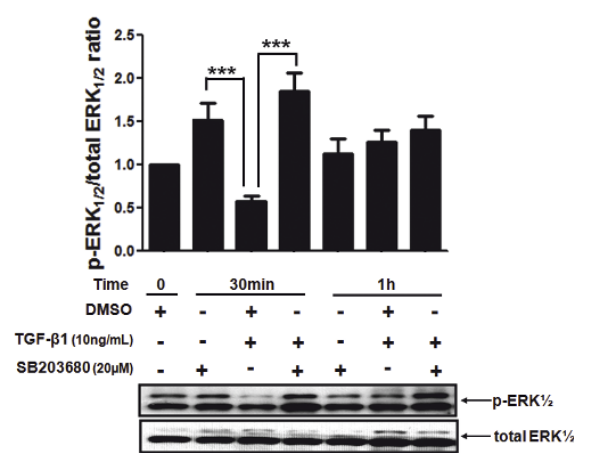

Figure 8 Phosphorylated and total protein expression levels of p38 MAPK and ERK1/2 in MDA-MB-231 cell line treated with specific inhibitors for these MAPKs and stimulated with TGF- $\beta 1$ for different periods of time. (A) MDA-MB-231 cells were pre-treated with $20 \mu \mathrm{M}$ of PD98059 (specific ERK1/2 pharmacological inhibitor) for $1 \mathrm{~h}$ and then stimulated with $10 \mathrm{ng} / \mathrm{mL}$ TGF- $\beta 1$ for different periods of time $(0,10$ min and $3 \mathrm{~h}$ ). Total protein lysates from these samples were used to analyze the protein expression levels of total and phosphorylated forms of p38 MAPK by Western blotting. (B) The phosphorylated and total protein expression levels of ERK 1/2 were measured by Western blotting in MDA-MB-231 cells pre-treated with $20 \mu \mathrm{M}$ of SB203680 (p38 MAPK pharmacological specific inhibitor) for $1 \mathrm{~h}$ and stimulated with $10 \mathrm{ng} / \mathrm{mL}$ TGF- $\beta 1$ for $0,30 \mathrm{~min}$ and $1 \mathrm{~h}$. These results were analyzed and used to calculate the p-p38 MAPK/total p38 MAPK and p-ERK1/2/total ERK1/2 ratios, respectively. Results are presented in graphics as mean \pm standard errors from three independent experiments. The Western blotting figures are representative of one experiment. ${ }^{*}, p<0.05,{ }^{* * *}$ and $p<0.001$, all versus control (cells treated with DMSO, vehicle).

frequently lost, mutated or attenuated in human carcinomas, including pancreatic, colon and gastric tumors $[43,44]$. Alternatively, other tumor types, such as breast tumors, present much lower mutation frequency in these TGF- $\beta$ signaling effectors, but display many alterations in their expression levels $[43,45,46]$. Only few reports addressed more than one TGF- $\beta$ pathway member at the same time. Due to the lack of information regarding profile complexity of the TGF- $\beta$ network elements and their dependence on the cell context, we first performed a general characterization of the TGF- $\beta$ isoforms and their receptors by mRNA expression analysis in a panel of five human breast cancer cell lines displaying diverse invasive and metastatic capacities. We showed that, similar to MMPs, TIMPs and RECK, the mRNA levels of TGF- $\beta$ receptors I and II, are expressed at a higher level in the most aggressive cell line, as compared to the less invasive ones, except for T $\beta R I$ that was also highly expressed in ZR-75-1 cells. These results corroborate prior reports in the literature from tumor tissue samples, showing that, in breast cancer models, TGF- $\beta$ signaling appears to be correlated with tumorpromoting functions $[23,47,48]$.

TGF- $\beta 1$ acts as a growth inhibitor at the early stages of tumorigenesis while it stimulates EMT, tumor invasion and metastasis in advanced tumors [40,41]. Therefore, cancer cells in different stages of aggressiveness respond differently to TGF- $\beta$ treatment. The least invasive (MCF-7) and the highly invasive (MDA-MB-231) human breast cancer cell lines are examples of this dual role of TGF- $\beta$. In this case, loss of estrogen receptor expression and ras gene amplification, two very common alterations during breast cancer progression, are some factors involved in switching the phenotypic response of TGF- $\beta$ treatment, from anti-proliferative to invasive [32]. Thus, TGF- $\beta 1$ is not able to regulate proliferation of the MDA-MB-231 cells $[28,49]$. However, we demonstrate that this cytokine is a positive modulator of migration and invasive potential of these cells.

Previous reports have suggested a crucial function of TGF- $\beta 1$ in cell motility control, some of which relate this altered phenotype to its role as a modulator of MMPs [23-27,50]. Kim and collaborators suggested that TGF- $\beta 1$ also induces invasion in pre-malignant breast cancer cells (MCF10A), by upregulation of MMP-2 and MMP-9 [21]. Subsequent reports also indicated that MMP- 2 and MMP-9 are essential in the TGF- $\beta 1$-incresead invasion of MCF10 cell series in a 3D model [23]. Similarly, the high motility phenotype presented by TGF- $\beta 1$-treated MDA-MB-231 cells was associated with the upregulation of MMP- 9 by this cytokine [50,51]. On the other hand, in the MDA-MB-435 cell line, MMP-14 was shown to be the molecule responsible for the TGF$\beta 1$-increased migration capacity [22]. However, none of these previous reports investigated whether TGF- $\beta 1$ can also modulate the expression of MMP inhibitors, and whether these inhibitors, thought to downmodulate ECM breakdown, are also implicated in the TGF- $\beta 1$ induced cell spreading. Since the balance between MMPs and their inhibitors is an important factor for ECM degradation, the identification of common regulators of MMPs, TIMPs and RECK is necessary to identify the principal factors involved in the metastatic process. Here we describe, for the first time, a molecular 


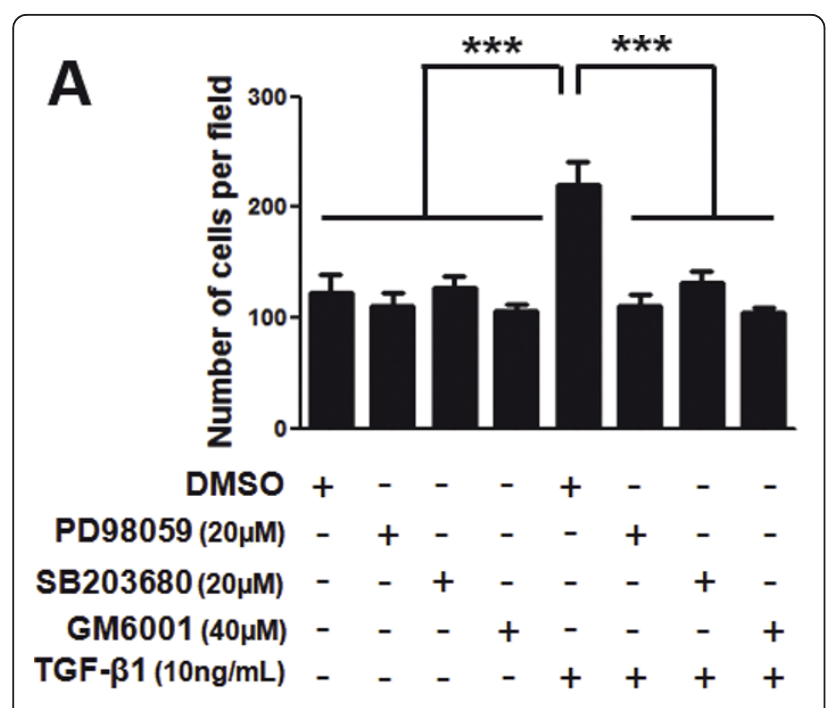

B
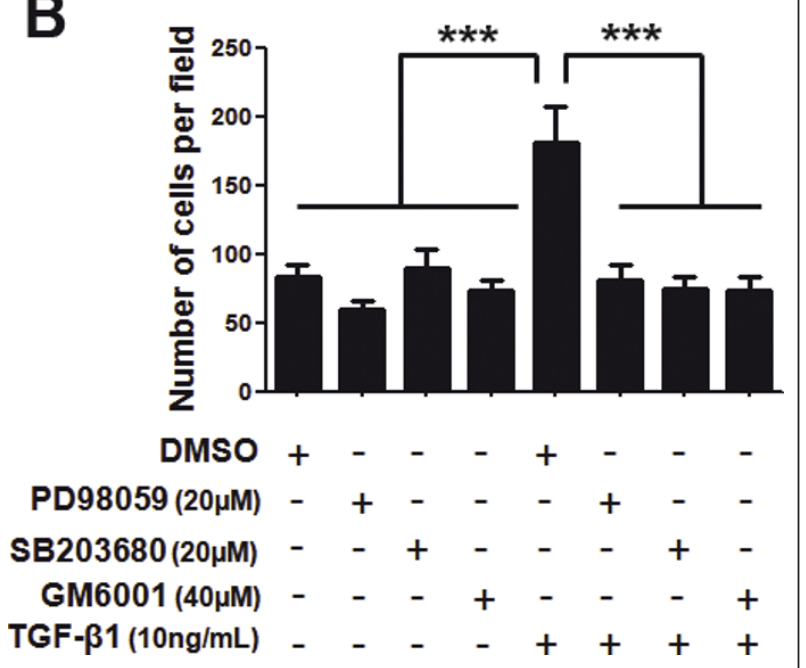

Figure 9 In vitro migration (A) and invasion (B) capacities of the MDA-MB-231 cell line upon treatment with TGF- $\beta 1$ and inhibitors of ERK1/2, p38 MAPK and MMPs. MDA-MB-231 cells were pre-treated for $1 \mathrm{~h}$ with $20 \mu \mathrm{M}$ of either PD98059 or SB203680 (ERK1/2 and p38 MAPK pharmacological inhibitor, respectively) or with $40 \mu \mathrm{M}$ of GM6001 (a broad-spectrum MMPs inhibitor). After the inhibition treatment these cells were stimulated with $10 \mathrm{ng} / \mathrm{mL}$ TGF- $\beta 1$ and allowed to migrate through uncoated transwells for $8 \mathrm{~h}$ (A) or invade through matrigel-coated transwells for $24 \mathrm{~h}$ (B). The number of cells at the bottom of the transwell filters was counted at the end of each assay. Results are presented as means \pm standard errors from three independent experiments, performed in duplicate, all versus control (cells treated with DMSO, vehicle).

mechanism in which TGF- $\beta 1$ modulates MMP- 2 and MMP-9 as well as TIMP-2 and RECK expression. The regulation of these MMPs inhibitors expression could be related to a cellular response for reestablishment of the proteases/inhibitors balance during cancer progression.
We found some discrepancy between the mRNA and protein expression levels of some MMPs and MMPs inhibitors upon treatment with TGF- $\beta 1$. For instance, while RECK was increased at the transcriptional level, its protein expression levels were inhibited by this cytokine. This divergence could be due to the influence of TGF- $\beta 1$ in RECK mRNA and protein stability and degradation rates and/or to other post-transcriptional and post-translational molecular mechanisms.

Although mounting evidence supports the potential role of RECK as a molecular marker for cancer prognosis and controller of cellular metastatic capacity, no reports are available unveiling its function in breast cancer $[18,19]$. For the first time, we have demonstrated that expression of this membrane-associated MMP inhibitor is regulated by TGF- $\beta 1$ in a breast cancer cell culture model, suggesting that RECK could be involved in the molecular mechanisms of breast cancer progression.

TGF- $\beta 1$ is able to signal through both Smad-dependent and Smad-independent mechanisms. However, previous evidences have established that each of these pathways is related to distinct cellular responses to TGF- $\beta 1[35,52]$. Therefore, the switching of TGF- $\beta$ 's role from a tumor suppressor to a pro-oncogenic-factor during cancer progression could be caused by changes in the way that this cytokine modulates its downstream pathways. It has been suggested that Smads are involved in the anti-tumor process, such as inhibition of cell proliferation, while the Smad-independent pathways have been implicated in induction of tumor progression $[35,52]$.

Here we analyzed the involvement of ERK1/2 and p38 MAPK, two well established Smad-independent pathways, in the proposed mechanism of coordinate regulation of MMPs, TIMPs and RECK by TGF- $\beta 1$ in breast cancer cell lines. Our results demonstrate that both MAPKs are important for this mechanism, each being responsible for modulating specific molecules (Figure 10). Unlike previously reported data of MCF10A cells [21], p38 MAPK as well as ERK1/2 were shown to be key components mediating the TGF- $\beta 1$-induced MMPs upregulation. However, our data show that p38 MAPK mediates increased levels of MMP-2 and ERK1/2 are involved in the modulation of MMP-9 levels. Although both p38 MAPK and ERK1/2 were required for TGF- $\beta 1$ induction of the TIMP-2 protein expression, we demonstrated that only ERK $1 / 2$ are responsible for the RECK downregulation induced upon TGF- $\beta 1$ treatment [21].

\section{Conclusions}

Taken together, the results obtained demonstrate that TGF- $\beta 1$ is a common regulator of MMPs (MMP-2 and MMP-9) and their inhibitors (TIMP-2 and RECK) in 


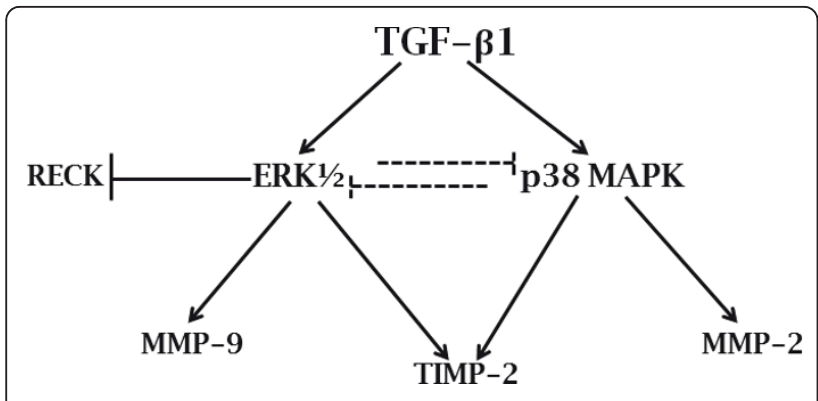

Figure 10 Scheme of the molecular mechanism proposed for TGF- $\beta 1$ action as a common regulator of MMPs (MMP-2 and MMP-9) and their inhibitors (TIMP-2 and RECK), through ERK1/ 2 and p38 MAPK pathways, in MDA-MB-231 cell line. The dashed lines indicate regulations suggested by preliminary experiments.

breast cancer cell models. Besides TGF- $\beta 1$ function in controlling extracellular matrix components synthesis [53], our results provide important evidence that this cytokine performs a central and intricate function in the control of the ECM status by the modulation of MMPs, TIMPs and RECK expression. Subsequent in vivo assays should be performed to further support our data. The TGF- $\beta 1$-mediated balance among these proteases and their specific inhibitors seems to be a result of the equilibrium between p38 MAPK and ERK1/2 activities (Figure 10). The crosstalk between the MAPK pathways shown here could also increase the complexity of this TGF- $\beta 1$ effect on cancer cells. Furthermore, the dosedependent TGF- $\beta 1$ functions on MMP- 9 and RECK protein levels emphasize the multifaceted mechanism of this cytokine in the control of tumor invasion and metastatic capacities. Thus, the promising application of clinical approaches based on TGF- $\beta 1$ targeting for breast cancer treatment may be very challenging, due to the complex and broad-spectrum actions of this cytokine in cancer progression and microenvironment architecture.

\section{Additional material}

Additional file 1: Analysis of the relative expression levels of PAI-I as a positive control for MDA-MB-231 cell line treatment with (A) recombinant TGF- $\beta 1$ or (B) TGF- $\beta 1$ bioactivity neutralizing antibody. The mRNA expression of PAl-I was analyzed by qRT-PCR using total RNA from the MDA-MB-231 cells treated with (A) $0,1,5$ or $10 \mathrm{ng} / \mathrm{mL}$ of recombinant TGF- $\beta 1$ for $20 \mathrm{~h}$ or (B) $0,1,10,25$ or $50 \mathrm{ng} / \mathrm{mL}$ of anti-TGF$\beta 1$ antibody for $24 \mathrm{~h}$. The results are presented as means \pm standard errors from two independent experiments. ${ }^{* *}, p<0.01$ and ${ }^{* *} p<0.001$, all versus control (untreated cell).

\section{Abbreviations}

ECM: Extracellular matrix; EMT: Epithelial-mesenchymal transition; ER: Estrogen receptor; ERK: Extracellular signal-regulated kinase 1/2; MAPK: Mitogen-activated protein kinase; MMP: Matrix metalloproteinases; p-ERK: Phosphorilated form of extracellular signal-regulated kinase 1/2; p-p38 MAPK:
Phosphorilated form of p38 MAPK; PR: Progesterone receptor; qRT-PCR: Quantitative reverse transcription polymerase chain reaction; RECK: Reversion-inducing cysteine-rich protein with Kazal motifs; TGF- $\beta 1$ : Transforming growth factor- $\beta$; TIMP: Tissue inhibitors of matrix metalloproteinases; T $\beta R$ : Receptor of Transforming growth factor- $\beta$.

\section{Acknowledgements}

We are deeply thankful to the excellent technical assistance provided by Zizi de Mendonça, Sandra Regina de Souza, Débora Cristina da Costa, Ricardo Krett de Oliveira and Marluce Mantovani and to Rita de Cássia Sávio Figueira's contribution, discussions and suggestions at the beginning of this work. We also thank Joni D. Mott for critical reviewing of this manuscript. This work was supported by Fundação de Amparo a Pesquisa do Estado de São Paulo (FAPESP), Conselho Nacional de Pesquisa (CNPq), Financiadora de Estudos e Projetos (FINEP), Coordenação de Aperfeiçoamento de Pessoal de Nível Superior (CAPES), Banco Nacional de Desenvolvimento Social e Econômico (BNDES - FUNTEC), Departamento de Ciência e Tecnologia em Saúde - Ministério da saúde (DECIT-MS) and Ministério de Ciência e Tecnologia (MCT).

\section{Authors' contributions}

LRG was responsible for most of the experimental work and results interpretation. LRG was also responsible for manuscript preparation. LFT and RAMW performed some experimental work. LL participated in the study design, data discussion and interpretation. MCS was involved in the study design and supervision. All authors read and approved the final manuscript.

\section{Competing interests}

The authors declare that they have no competing interests.

Received: 17 November 2011 Accepted: 19 January 2012

Published: 19 January 2012

\section{References}

1. Jemal A, Siegel R, Xu J, Ward E: Cancer Statistics, 2010. CA Cancer J Clin 2010, 60:277-300.

2. Bertucci F, Birnbaum D: Distant metastasis: not out of reach any more. $J$ Biol 2009, 8:28.

3. Boyd D: Invasion and metastasis. Cancer Metastasis Rev 1996, 15:77-89.

4. Chambers AF: The metastatic process: basic research and clinical implications. Oncol Res 1999, 11:161-168.

5. Ruoslahti E: How cancer spreads. Sci Am 1996, 275:72-77.

6. Deryugina El, Quigley JP: Matrix metalloproteinases and tumor metastasis. Cancer Metastasis Rev 2006, 25:9-34.

7. Radisky ES, Radisky DC: Matrix metalloproteinase-induced epithelialmesenchymal transition in breast cancer. J Mammary Gland Biol Neoplasia 2010, 15:201-212.

8. Lambert E, Dasse E, Haye B, Petitfrere E: TIMPs as multifacial proteins. Crit Rev Oncol Hematol 2004, 49:187-198.

9. Clark JC, Thomas DM, Choong PF, Dass CR: RECK-a newly discovered inhibitor of metastasis with prognostic significance in multiple forms of cancer. Cancer Metastasis Rev 2007, 26:675-683.

10. Mott JD, Werb Z: Regulation of matrix biology by matrix metalloproteinases. Curr Opin Cell Biol 2004, 16:558-564.

11. McGowan PM, Duffy MJ: Matrix metalloproteinase expression and outcome in patients with breast cancer: analysis of a published database. Ann Oncol 2008, 19:1566-1572.

12. Figueira RC, Gomes LR, Neto JS, Silva FC, Silva ID, Sogayar MC: Correlation between MMPs and their inhibitors in breast cancer tumor tissue specimens and in cell lines with different metastatic potential. BMC Cancer 2009, 9:20.

13. Jezierska A, Motyl T: Matrix metalloproteinase-2 involvement in breast cancer progression: a mini-review. Med Sci Monit 2009, 15:RA32-40.

14. Shah FD, Shukla SN, Shah PM, Shukla HK, Patel PS: Clinical significance of matrix metalloproteinase 2 and 9 in breast cancer. Indian $J$ Cancer 2009, 46:194-202.

15. Ishigaki S, Toi M, Ueno T, Matsumoto H, Muta M, Koike M, Seiki M: Significance of membrane type 1 matrix metalloproteinase expression in breast cancer. Jpn J Cancer Res 1999, 90:516-522.

16. Liss M, Sreedhar N, Keshgegian A, Sauter G, Chernick MR, Prendergast GC, Wallon UM: Tissue inhibitor of metalloproteinase-4 is elevated in early- 
stage breast cancers with accelerated progression and poor clinical course. Am J Pathol 2009, 175:940-946.

17. Kuvaja P, Wurtz SO, Talvensaari-Mattila A, Brunner N, Paakko P, Turpeenniemi-Hujanen T: High serum TIMP-1 correlates with poor prognosis in breast carcinoma - a validation study. Cancer Biomark 2007, 3:293-300.

18. Takahashi C, Sheng Z, Horan TP, Kitayama H, Maki M, Hitomi K, Kitaura Y, Takai S, Sasahara RM, Horimoto A, Ikawa Y, Ratzkin BJ, Arakawa T, Noda M: Regulation of matrix metalloproteinase-9 and inhibition of tumor invasion by the membrane-anchored glycoprotein RECK. Proc Natl Acad Sci USA 1998, 95:13221-13226.

19. Noda M, Takahashi C: Recklessness as a hallmark of aggressive cancer. Cancer Sci 2007, 98:1659-1665.

20. Sun L, Diamond ME, Ottaviano AJ, Joseph MJ, Ananthanarayan V, Munshi HG: Transforming growth factor-beta 1 promotes matrix metalloproteinase-9-mediated oral cancer invasion through snail expression. Mol Cancer Res 2008, 6:10-20.

21. Kim ES, Kim MS, Moon A: TGF-beta-induced upregulation of MMP-2 and MMP-9 depends on $\mathrm{p} 38$ MAPK, but not ERK signaling in MCF10A human breast epithelial cells. Int J Oncol 2004, 25:1375-1382.

22. Kuo YC, Su CH, Liu CY, Chen TH, Chen CP, Wang HS: Transforming growth factor-beta induces CD44 cleavage that promotes migration of MDA$\mathrm{MB}-435 \mathrm{~s}$ cells through the up-regulation of membrane type 1-matrix metalloproteinase. Int J Cancer 2009, 124:2568-2576.

23. Wiercinska E, Naber HP, Pardali E, van der Pluijm G, van Dam H, Ten Dijke P. The TGF-beta/Smad pathway induces breast cancer cell invasion through the up-regulation of matrix metalloproteinase 2 and 9 in a spheroid invasion model system. Breast Cancer Res Treat 2010, 128:657-666.

24. Hsieh HL, Wang HH, Wu WB, Chu PJ, Yang CM: Transforming growth factor-beta 1 induces matrix metalloproteinase- 9 and cell migration in astrocytes: roles of ROS-dependent ERK- and JNK-NF-kappaB pathways. J Neuroinflammation 2010, 7:88.

25. Lee H, Lim C, Lee J, Kim N, Bang S, Min B, Park G, Noda M, StetlerStevenson WG, Oh J: TGF-beta signaling preserves RECK expression in activated pancreatic stellate cells. J Cell Biochem 2008, 104:1065-1074.

26. Munshi HG, Wu YI, Mukhopadhyay S, Ottaviano AJ, Sassano A, Koblinski JE, Platanias LC, Stack MS: Differential regulation of membrane type 1-matrix metalloproteinase activity by ERK $1 / 2$ - and p38 MAPK-modulated tissue inhibitor of metalloproteinases 2 expression controls transforming growth factor-beta1-induced pericellular collagenolysis. J Biol Chem 2004, 279:39042-39050.

27. Zhong J, Gencay MM, Bubendorf L, Burgess JK, Parson H, Robinson BW, Tamm M, Black JL, Roth M: ERK1/2 and p38 MAP kinase control MMP-2, MT1-MMP, and TIMP action and affect cell migration: a comparison between mesothelioma and mesothelial cells. J Cell Physiol 2006, 207:540-552.

28. Farina AR, Coppa A, Tiberio A, Tacconelli A, Turco A, Colletta G, Gulino A, Mackay AR: Transforming growth factor-beta1 enhances the invasiveness of human MDA-MB-231 breast cancer cells by up-regulating urokinase activity. Int J Cancer 1998, 75:721-730

29. Rahimi RA, Leof EB: TGF-beta signaling: a tale of two responses. J Cell Biochem 2007, 102:593-608.

30. Massague J, Blain SW, Lo RS: TGFbeta signaling in growth control, cancer, and heritable disorders. Cell 2000, 103:295-309.

31. Heldin $\mathrm{CH}$, Landstrom M, Moustakas A: Mechanism of TGF-beta signaling to growth arrest, apoptosis, and epithelial-mesenchymal transition. Curr Opin Cell Biol 2009, 21:166-176.

32. Wilson CA, Cajulis EE, Green JL, Olsen TM, Chung YA, Damore MA, Dering J, Calzone FJ, Slamon DJ: HER-2 overexpression differentially alters transforming growth factor-beta responses in luminal versus mesenchymal human breast cancer cells. Breast Cancer Res 2005, 7: R1058-1079.

33. Pardali K, Moustakas A: Actions of TGF-beta as tumor suppressor and prometastatic factor in human cancer. Biochim Biophys Acta 2007, 1775:21-62.

34. Gomes LR, Terra LF, Sogayar MC, Labriola L: Epithelial-Mesenchymal Transition: Implications in Cancer Progression and Metastasis. Curr Pharm Biotechnol 2011, 12:1881-1890.

35. Giehl $K$, Imamichi Y, Menke A: Smad4-independent TGF-beta signaling in tumor cell migration. Cells Tissues Organs 2007, 185:123-130.
36. Vandesompele J, De Preter K, Pattyn F, Poppe B, Van Roy N, De Paepe A, Speleman F: Accurate normalization of real-time quantitative RT-PCR data by geometric averaging of multiple internal control genes. Genome Biol 2001, 3:0034.1-0034.12.

37. Pfaffl MW: A new mathematical model for relative quantification in realtime RT-PCR. Nucleic Acids Res 2001, 29:2002-2007.

38. Heussen C, Dowdle EB: Electrophoretic analysis of plasminogen activators in polyacrylamide gels containing sodium dodecyl sulfate and copolymerized substrates. Anal Biochem 1980, 102:196-202.

39. Bachmeier BE, Albini A, Vene R, Benelli R, Noonan D, Weigert C, Weiler C, Lichtinghagen R, Jochum M, Nerlich AG: Cell density-dependent regulation of matrix metalloproteinase and TIMP expression in differently tumorigenic breast cancer cell lines. Exp Cell Res 2005, 305:83-98

40. Jakowlew SB: Transforming growth factor-beta in cancer and metastasis. Cancer Metastasis Rev 2006, 25:435-457.

41. Meulmeester E, Ten Dijke P: The dynamic roles of TGF-beta in cancer. J Pathol 2011, 223:205-218

42. Hanahan D, Weinberg RA: The hallmarks of cancer. Cell 2000, 100:57-70.

43. Padua D, Massague J: Roles of TGFbeta in metastasis. Cell Res 2009, 19:89-102.

44. Bierie B, Moses HL: Gain or loss of TGFbeta signaling in mammary carcinoma cells can promote metastasis. Cell Cycle 2009, 8:3319-3327.

45. Desruisseau S, Palmari J, Giusti C, Romain S, Martin PM, Berthois Y: Determination of TGFbeta1 protein level in human primary breast cancers and its relationship with survival. Br J Cancer 2006, 94:239-246.

46. Ivanovic V, Todorovic-Rakovic N, Demajo M, Neskovic-Konstantinovic Z, Subota V, Ivanisevic-Milovanovic O, Nikolic-Vukosavljevic D: Elevated plasma levels of transforming growth factor-beta 1 (TGF-beta 1) in patients with advanced breast cancer: association with disease progression. Eur J Cancer 2003, 39:454-461.

47. Ganapathy V, Ge R, Grazioli A, Xie W, Banach-Petrosky W, Kang Y, Lonning S, McPherson J, Yingling JM, Biswas S, Mundy GR, Reiss M: Targeting the Transforming Growth Factor-beta pathway inhibits human basal-like breast cancer metastasis. Mol Cancer 2010, 9:122.

48. Hoshino Y, Katsuno Y, Ehata S, Miyazono K: Autocrine TGF-beta protects breast cancer cells from apoptosis through reduction of BH3-only protein, Bim. J Biochem 2011, 149:55-65.

49. Duivenvoorden WC, Hirte HW, Singh G: Transforming growth factor beta1 acts as an inducer of matrix metalloproteinase expression and activity in human bone-metastasizing cancer cells. Clin Exp Metastasis 1999, 17:27-34.

50. Safina A, Ren MQ, Vandette E, Bakin AV: TAK1 is required for TGF-beta 1mediated regulation of matrix metalloproteinase- 9 and metastasis. Oncogene 2008, 27:1198-1207.

51. Suarez-Cuervo C, Merrell MA, Watson L, Harris KW, Rosenthal EL, Vaananen HK, Selander KS: Breast cancer cells with inhibition of p38alpha have decreased MMP-9 activity and exhibit decreased bone metastasis in mice. Clin Exp Metastasis 2004, 21:525-533.

52. Nagaraj NS, Datta PK: Targeting the transforming growth factor-beta signaling pathway in human cancer. Expert Opin Investig Drugs 2010, 19:77-91.

53. Verrecchia F, Mauviel A: Transforming growth factor-beta signaling through the Smad pathway: role in extracellular matrix gene expression and regulation. J Invest Dermatol 2001, 118:211-215.

\section{Pre-publication history}

The pre-publication history for this paper can be accessed here: http://www.biomedcentral.com/1471-2407/12/26/prepub

\section{doi:10.1186/1471-2407-12-26}

Cite this article as: Gomes et al: TGF- $\beta 1$ modulates the homeostasis between MMPs and MMP inhibitors through p38 MAPK and ERK1/2 in highly invasive breast cancer cells. BMC Cancer 2012 12:26. 